\title{
In vitro Anticancer Evaluation of Saponins Obtained From Spirulina platensis on MDA, HepG2, and MCF7 Cell Lines
}

DOI: 10.30699 /acadpub.mci.3.4.25

\author{
Mahboobeh Akbarizare ${ }^{1}$, Hamideh Ofoghi ${ }^{1{ }^{1 *},}$ Mahnaz Hadizadeh ${ }^{1}$ \\ ${ }^{1}$ Department of Biotechnology, Iranian Research Organization for Science and \\ Technology (IROST), Tehran, Iran \\ *Corresponding author: Hamideh Ofoghi, Department of Biotechnology, \\ Iranian Research Organization for Science and Technology (IROST), Zip Code: \\ 3313193685, Tehran, Iran. Tel: +982156276325-9; Fax: +982156276636; \\ E-mail: ofoghi@irost.ir
}

Submitted: 21 August 2019

Revised: 12 September 2019

Accepted: 24 September 2019

e-Published: 1 October 2019

Keywords:

Microalgae

Antineoplastic Agents

Saponins

Spirulina

Chromatography, Thin Layer

\begin{abstract}
Introduction: Microalgae are known for their bioactive compounds with potential applications as antimicrobial, antiaging, and anticancer activities. Spirulina platensis $(S$. platensis) is a filamentous and photosynthetic microorganism that has 25 kinds of vitamins and minerals that contain many compounds with biotic activity such as alkaloids, phenolic compounds, terpenoids, and saponins. Saponins are mainly present in plants; while there are few studies about their role in microalgae. This study aims to investigate the anticancer potential of extracted saponins from $S$. platensis.

Methods: Saponins were extracted; using distilled water and n-butanol. The total extracted saponin was dried and weighed. The cellular viability of HepG2, MCF-7, and MDAMB-123 cell lines was evaluated; using MTT assay after $24 \mathrm{~h}$ treatment with $0.02-2 \mathrm{mg} /$ $\mathrm{ml}$ of saponins extracted from $S$. platensis. Morphology of cell lines was evaluated by invert microscopy.
\end{abstract}

Results: Total saponin extracted from $S$. platensis was estimated at $28 \pm 0.0005 \mathrm{mg} / \mathrm{g}$ dry wt. Thin-layer chromatography profiles showed four bands for saponins with Rf values of $0.44,0.48,0.50$, and 0.55 . The cytotoxic activity after $24 \mathrm{~h}$ treatment with $0.02-2 \mathrm{mg} / \mathrm{ml}$ of saponins was a concentration-dependent manner. The highest toxicity of saponins with IC50 $=0.22 \mathrm{mg} / \mathrm{ml}$ was observed in MDA-MB-123 cells. In HepG2 and MCF-7 cells IC50 value was obtained in $0.35 \mathrm{mg} / \mathrm{ml}$ and $0.4 \mathrm{mg} / \mathrm{ml}$, respectively.

Conclusions: This is the first report to evaluate the anticancer effects of saponins from $S$. platensis in liver and breast cancers. The result showed that saponins from Spirulina decrease cancer cellular viability. Therefore, these compounds can be a candidate for anticancer agents.

(C) 2019. Multidisciplinary Cancer Investigation

\section{INTRODUCTION}

Marine microalgae are new sources of a vast number of bioactive compounds that are applied in pharmaceutical agents [1]. A lot of bioactive compounds isolated from cyanobacteria made this group an exciting target for further researches [2]. Among cyanobacteria, Spirulina platensis (S.

platensis) was well known as an edible blue-green, photosynthetic microalga with a filamentous shape and relatively simple requirements for growth. $S$. platensis includes many compounds such as alkaloids, saponins, phenols, and flavonoids with biological activities [3-7]. Saponins are secondary 
metabolites that are mainly found in plants. These components are usually characterized by the presence of asteroidal or triterpenoid aglycone and one or more sugar chains [8]. Saponins declare various biotic effects such as anticancer activity, immunoregulatory, antiviral, and antibacterial effects $[8,9]$. Panax ginseng or Glycyrrhiza glabra are two plants that have been used for pharmaceutical purposes since ancient times because of their saponins. Steroidal saponins have been used for the production of steroidal hormones in pharmaceutical industries. Cytotoxic effect of saponins isolated from different parts of several plants such as Dioscorea colletti var, hypoglauca, Cimicifuga sp, Aesculus pavia. Solanum nigrum and Gordonia chrysandra were assessed on different cancer cell lines. In the majority of cases, cytotoxicity of isolated saponins was comparable with reference substance anticancer agents such as etoposide and paclitaxel [10]. There are some studies on saponins extracted from Chinese medicines. For example, Saikosaponin (one of the saponins isolated from Ginseng radix) has antiproliferation activity on MCF7, MDA-MB-231, and HepG2 cell lines. Dioscin is a steroid saponin that was isolated from various Chinese plants such as Dioscoreae rhizome and Paridis rhizome. Polyphyllin D that was isolated from Paridis rhizome has also shown cytotoxic effects on HepG2, MCF7, and MDAcell lines [9]. Three brominated triterpenes isolated from the red seaweed Laurencia viridis have displayed cytotoxic activity against some of cancer cell lines. Furthermore, five triterpenoids saponins were extracted from Japanese red alga Laurencia obtuse and and two same compounds were isolated from brown algae Kjellmaniella crassifolia with cytotoxic activity [11]. So, saponins are a promising approach for new anticancer agents, however, in $S$. platensis, saponins have been less considered. The aim of this study was the estimation of total saponin content and its cytotoxic effects on selected cell lines.

\section{METHODS}

S. platensis was obtained from Algae culture collection of food biotechnology research institute, ABRII, Tabriz, Iran. After a microscopic evaluation (Figure 1), it was grown in Zarrouk medium [12, 13]. Zarrouk medium is composed of various compounds (Table 1). Each of the salts needed to make the Zarrouk medium was purchased from Merck company.

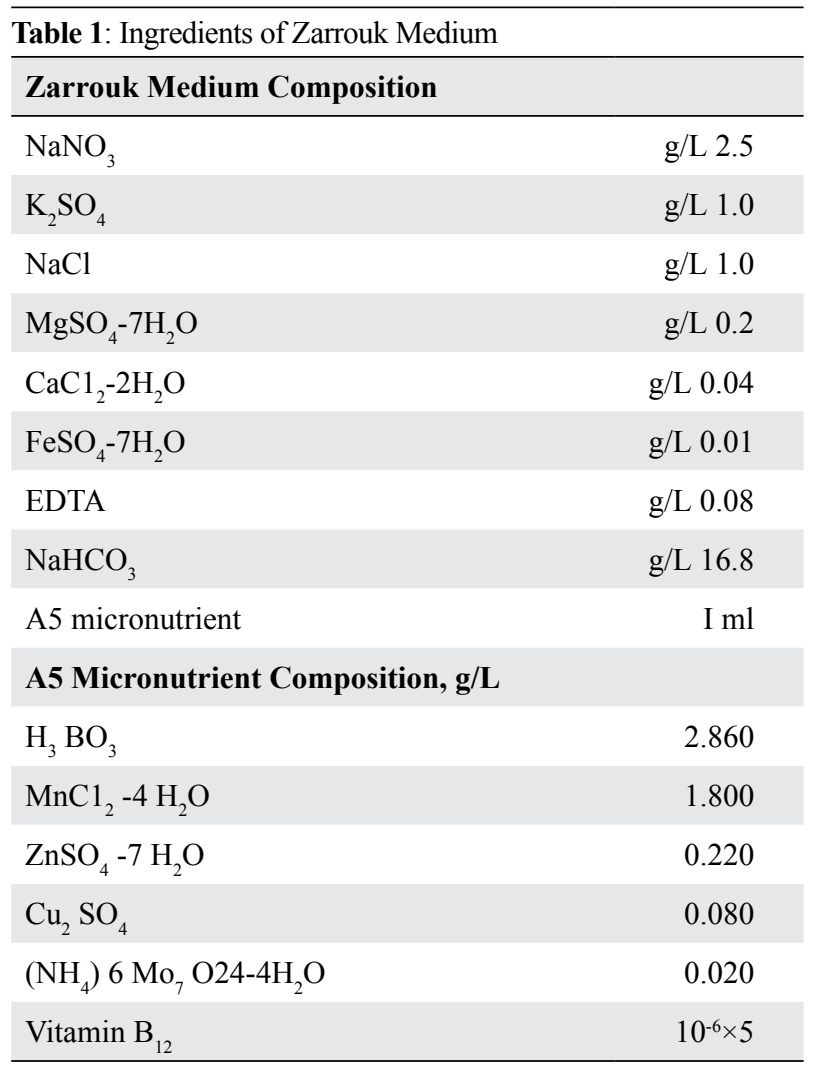

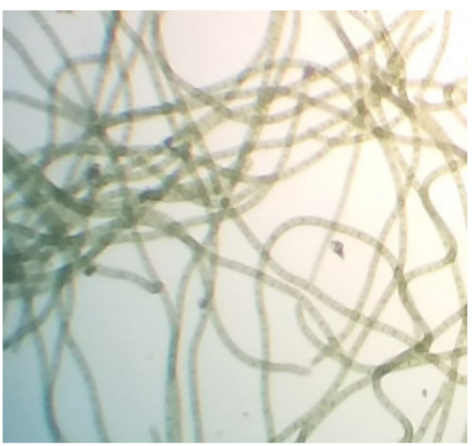

A

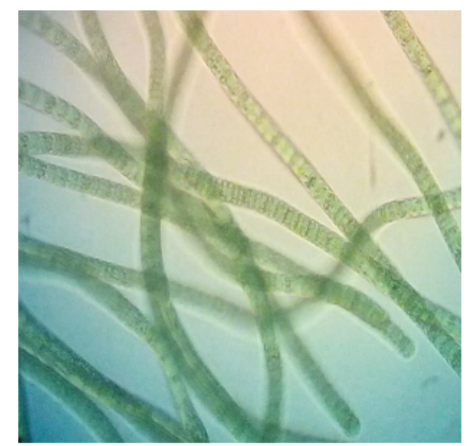

B

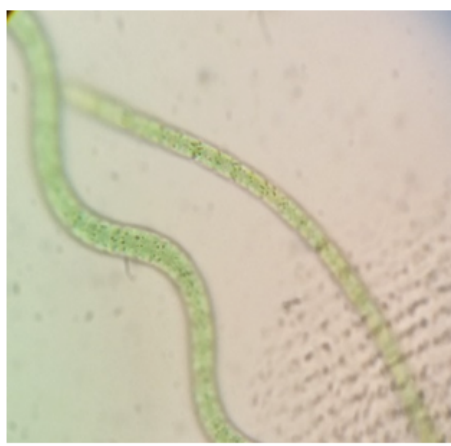

C

Figure 1: Light Microscopic Observation of S. platensis

A) Magnification X10; B) Magnification X40; C) Magnification X100 
S. platensis was first cultured in 250-ml glass Erlenmeyer flasks in $\mathrm{pH} 10$ at $30 \pm 2^{\circ} \mathrm{C}$ with the illumination of $4 \mathrm{~K}$.lux light intensity in batch culture system $[12,13]$. In the next step, mature cultures were inoculated in polyethylene containers to increase the production of biomass. The harvested biomass of Spirulina was dried; using the freeze drier method and was stored at $2-4^{\circ} \mathrm{C}$.

\section{Extraction of Saponins}

Methanolic extract of $5 \mathrm{~g}$ of $S$. platensis biomass in $30 \mathrm{ml}$ methanol $99 \%$ was extracted and dried at $40^{\circ} \mathrm{C}$. To obtain saponins, $5 \mathrm{ml}$ of distilled water and $5 \mathrm{ml}$ of waterlogged butanol were added to $0.05 \mathrm{~g}$ of dried methanolic extract. Saponins that were collected in the organic phase was separated and dried in the oven at $40^{\circ} \mathrm{C}$ [14]. To estimate total saponins, isolated saponins were weighted.

\section{Thin-Layer Chromatography}

To determine the purity of isolated saponins and optimization of the solvent system, thin-layer chromatography was used as a simple and inexpensive method. The isolated saponins from S. platensis were dissolved in dimethyl sulfoxide (DMSO) $10 \%$ and 20 $\mu \mathrm{l}$ of solution were spotted on pre-coated silica gel 60 F264 plates. As a solvent system, for the separation of saponins, a mixture of Ammonium: ethanol: n-butanol (7.5: 2.5: 10.5) (V: V: V) was used. Spots of saponins appeared after sprayed with $15 \%$ sulfuric acid solution and incubated in the oven at $110^{\circ} \mathrm{C}$ for 10 minutes. The plate was observed in UV light and the Retention factor (Rf) value of each spot was calculated by the following formula: $\mathrm{Rf}$ value $=$ distance moved by the solvent / distance moved by the test solution $[14,15]$. In this study, a mixture of saponin fractions was used for treatments.

\section{Cell Culture and In Vitro Evaluation of Anti- Proliferation Activity}

HepG2 (from the liver), MCF-7, MDA-MB-123 (from mammary gland/breast; derived from a metastatic site), and human dermal fibroblast (HDF) were purchased from Avicenna Research Institute. To evaluate the effect of saponins on normal cells, the HDF cell line was used as normal cells (control). Cell lines were cultured in RPMI-1640 medium (Gibco, USA); containing 10\% fetal bovine serum (FBS) and Penicillin (100U/mL)/Streptomycin $(100 \mathrm{U} / \mathrm{mL}),(\mathrm{Gibco}, \mathrm{USA})$ and were incubated with $5 \% \mathrm{CO} 2$ at $37^{\circ} \mathrm{C}[16]$. After $48 \mathrm{~h}$, it was observed by an inverted microscope and it was shown that $80 \%$ of the flask has been filled. The cells were then treated by trypsin and centrifuged in $1500 \mathrm{rpm}$ for 5 minutes at $2-8^{\circ} \mathrm{C}$. The pellet of each cell line was distributed in a 96-well plate at the cell density of approximately $1 \times 104$ cells/well and was maintained for $24 \mathrm{~h}$ to make sure that the cells were stuck to the plate [7]. The cells were treated with a serial dilution of isolated saponins $(0.02-2) \mathrm{mg} / \mathrm{ml}$ for $24 \mathrm{~h}$ and were then incubated at $37^{\circ} \mathrm{C}$ in the $\mathrm{CO} 2$ incubator. At the end of the incubation, $100 \mu \mathrm{L}$ of MTT solution $(0.5 \mathrm{mg} / \mathrm{ml})$ was added to each well. The plate was incubated for 3 to $4 \mathrm{~h}$. Following incubation, most of the solution in each well was discarded and $100 \mu \mathrm{L}$ of DMSO was added to each well and the solution was pipetted thoroughly. The adsorb of each well was read; using a microplate ELISA reader (Bio Tek -USA) at the wavelength of $570 \mathrm{~nm}$ [7].

Evaluation of Morphological Changes in Cells

The morphology and viability of different cancer cells were observed by an inverted microscope (CetiInverso TC-100) with a magnification of $40 \times$ after $24 \mathrm{~h}$ of incubation with $0.02-2 \mathrm{mg} / \mathrm{ml}$ of the saponins extracts from $S$. platensis.

\section{Statistical Analysis}

Data obtained from MTT assay for the evaluation of the effect of different concentrations of saponin on cellular viability was analyzed with Minitab version 16; using one-way ANOVA followed by Tukey tests. $\mathrm{P}<0.05$ was deliberated as statistically significant.

\section{RESULTS}

\section{Microscopic Observation of S. platensis}

Microscopic observations indicated that the strain obtained from the ABRII institute was completely pure with no microbial contamination (Figure 1).

\section{Total Saponin Content}

Isolated saponins of the inorganic phase of a mixture of distilled water and waterlogged n-butanol from S. platensis were dried at $40^{\circ} \mathrm{C}$ and weighed. Total saponins content was estimated at $28 \pm 0.0005 \mathrm{mg} / \mathrm{g}$ dry wt of $S$. platensis.

\section{Thin-Layer Chromatography}

As shown in Figure 2, four different spots of the isolated saponins from $S$. platensis were appeared on pre-coated silica gel 60 F264 plates with UV treatment after being sprayed with $15 \%$ sulfuric acid solution (Rf values: $0.44,0.48,0.50,0.55$ ). 


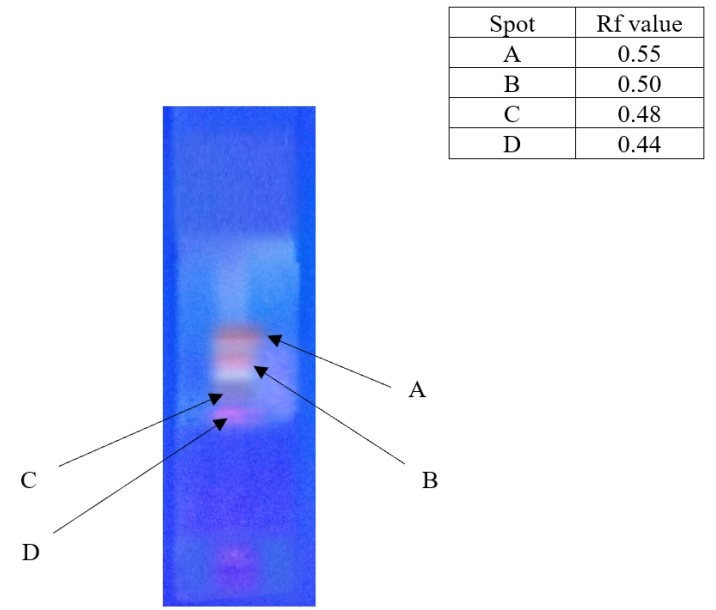

Figure 2: The TLC Profile of Isolated Saponins From S. platensis With UV treatment After Being Sprayed With Sulfuric Acid Solution 15\%
Antiproliferation Activity of Saponins, Isolated From S. platensis on HepG2, MCF7, and MDA Cell Lines

The proliferation activity of HepG2, MCF7, and MDA cell lines was inhibited by being treated with different concentrations $(0.02-2 \mathrm{mg} / \mathrm{ml})$ of isolated saponins from $S$. platensis. The anti-proliferation activity was a concentration-dependent manner. Comparison of the mean cellular viability of treated cells in three cell lines showed a significant difference between MDA cells and two other cell lines (HepG2 and MCf7) in 0.05 to $1 \mathrm{mg} / \mathrm{ml}$ of treated concentration and there was not a significant difference between HepG2 cells and MCF7 cells in the same treated concentration (Figure 3D). The dose-dependent effect of saponins isolated from Spirulina on cellular viability of MDA, MCF7,

Table 2: IC50 Values Obtained for Isolated Saponins From S. platensis on HepG2, MCF7, and MDA Cells (n=3) ${ }^{\text {a, }}$

\begin{tabular}{lccccc}
\hline Cell line & HepG2 & MCF-7 & MDA-MB-231 & HDF & Control (DMSO 1\%) \\
\hline IC50 Value of Total Saponins, $\mathbf{~ m g / m l ~}$ & $0.350 \pm 0.055$ & $0.400 \pm 0.036$ & $0.220 \pm 0.038$ & $2.6 \pm 0.1$ & - \\
\hline
\end{tabular}

${ }^{a}$ Values are mean \pm SD.

${ }^{\mathrm{b}}$ DMSO $1 \%$ was used as solvent and control that had no cytotoxicity effect on different cell lines.
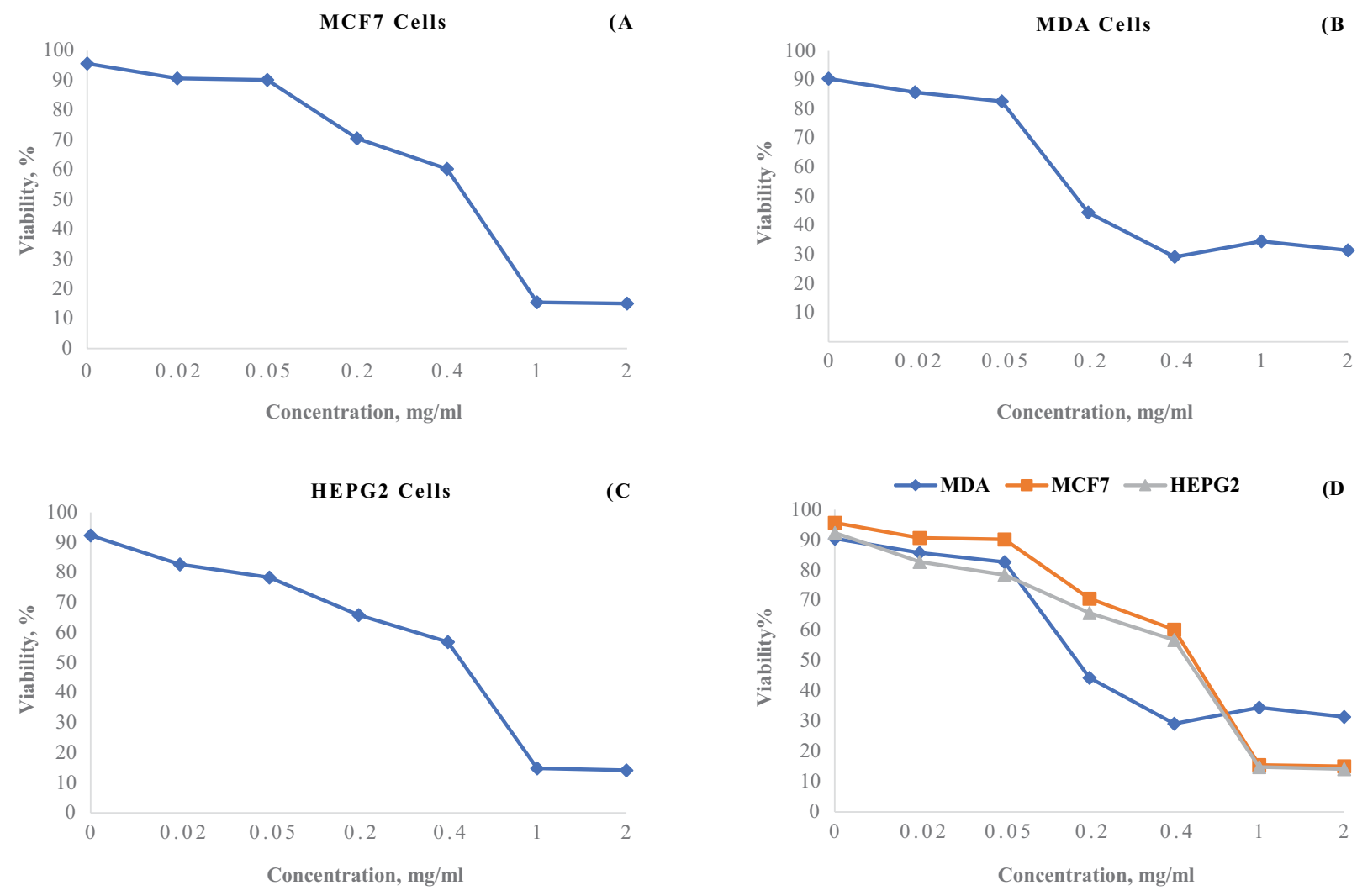

Figure 3: Cellular Viability in Cancer Cell Lines

A) MCF-7; B) MDA-MB-123; C) HepG2; D) Compare between three cancer cells; after being treated with 0.02-2 mg/ml of isolated saponins from $S$. platensis 
A1

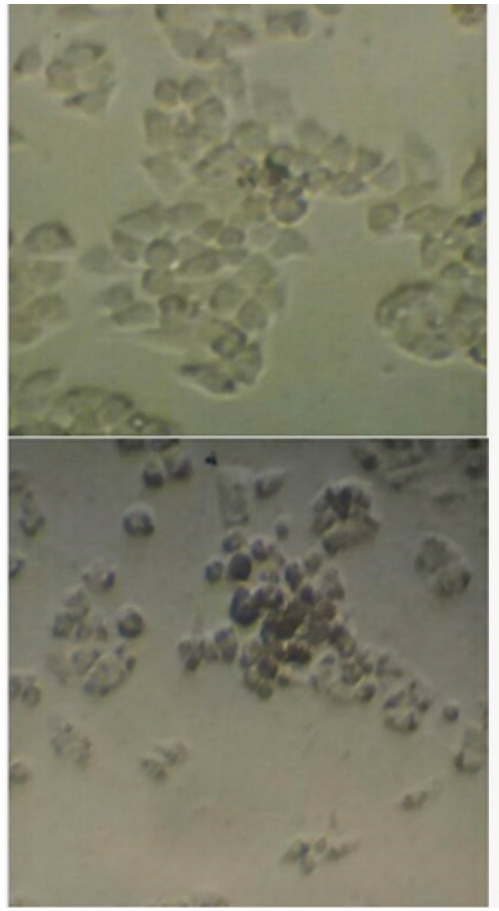

A2
B1

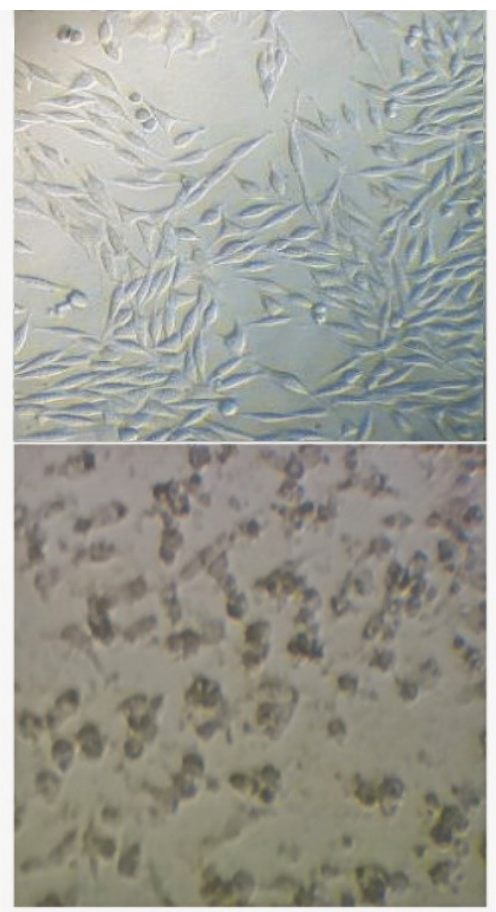

B2
C1

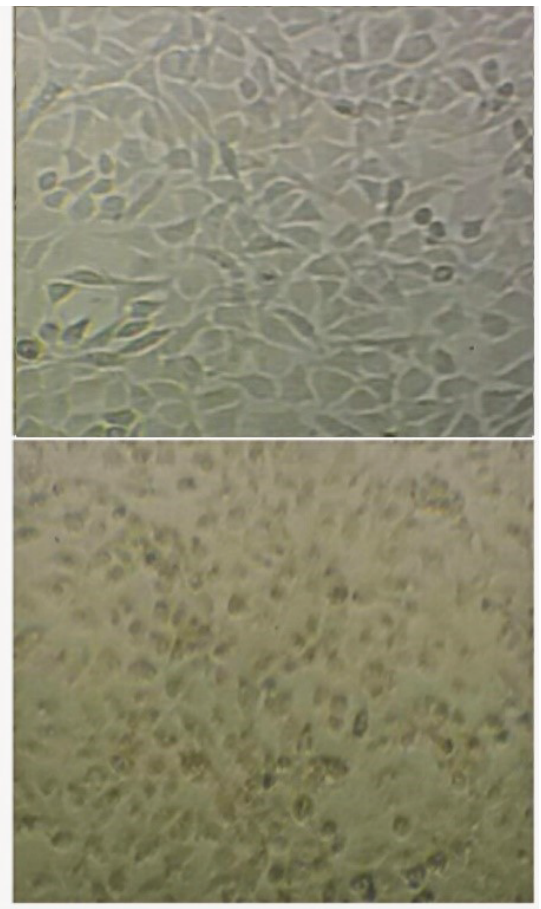

$\mathrm{C2}$

Figure 4: A1) Morphological Changes of Cell Lines After 24h Treatment With Isolated Saponins From S. platensis; A2) HepG2 Cells Treated With 0.3 $\mathrm{mg} / \mathrm{ml}$ of Saponins; B1) MDA Cells; B2) MDA Cells Treated With $0.2 \mathrm{mg} / \mathrm{ml}$ of Saponins; C1) MCF-7 Cells; C2) MCF-7 Cells Treated With $0.4 \mathrm{mg} /$ $\mathrm{ml}$ of Saponins

and HepG2 cell lines was analyzed by one- way ANOVA. Tukey test indicated that in 0.02 and $0.2 \mathrm{mg} / \mathrm{ml}$ of treated concentration, there was no significant difference between treated cells with saponins and untreated cells in none of the cell lines. Statistical analysis indicated a significant difference between different concentrations $(0.05$ to $1 \mathrm{mg} / \mathrm{ml})$ of treated and untreated cells in HepG2 and MCF7 cells. A high concentration of saponins $(1 \mathrm{mg} / \mathrm{ml})$ decreased the cellular viability whereas $0.05 \mathrm{mg} /$ $\mathrm{ml}$ and lower concentrations of saponins had no significant effect on tumor cell growth inhibition. In addition, there was a significant difference between different concentrations ( 0.05 to $0.4 \mathrm{mg} / \mathrm{ml})$ of treated and untreated cells in MDA cells. There was no significant difference between the results of treatment with 0.4 to $2 \mathrm{mg} / \mathrm{ml}$ of saponins in MDA cells and the results of treatment with 1 and $2 \mathrm{mg} / \mathrm{ml}$ of saponins in HepG2 and MCF7 cells $(\mathrm{P}<0.05)$. In grouping information analysis using Tukey test, R2 values were 97.42, 92.15, and 93.89 in MDA, MCF7, and HepG2 cell lines, respectively. The cellular viability after treatment with saponins from Spirulina was compared in HepG2, MCF7, and MDA cells (Figure 3). Cellular viability in the
HDF cell line in a similar concentration of isolated saponins was evaluated and the IC50 value was calculated $(2.6 \pm 0.1 \mathrm{mg} / \mathrm{ml})$.

The IC50 value (concentration inhibitory maximal) of each cell line was calculated after treatment; using the following formula: rate of cells viability $\%$ $=(\mathrm{OD} 570$ of treated cells/OD570 of control cells) $\times 100$ (Table 2).

\section{Evaluation of Morphological Changes in Cancer Cells}

Microscopic observation of each cell line showed that the cells were deformed after treatment with saponins at IC50 concentration compared to untreated cells. In HepG2 and MCF7 cell lines, the cells displayed characteristic features and changed into a spherical shape. Decomposed and bursting cells were observed in MDA cells (Figure 4). At higher concentrations ( 1 and $2 \mathrm{mg} / \mathrm{ml}$ ) modified cells were detached from the flask surface and floated in the medium.

\section{DISCUSSION}

$S$. platensis is an edible, multicellular blue-green microalga with a spiral form that can grow well 
in seawater and freshwater. It has a long history of safe human consumption [5]. The microalgae were widely studied for bioactive compounds such as alkaloids, phenols, terpenoids, antioxidant, anticancer, and antimicrobial activities [5, 13, 17]. Saponins are essential compounds with substantial biological activities such as anti-angiogenesis, antiproliferation, anticancer, and anti-metastasis characteristics. Saponins can reduce cell growth and inhibit DNA synthesis that can induce apoptosis of cancer cells by activation of caspase 2, caspase 3 , and caspase 8 [9]. Wang et al., have reported the cytotoxicity of saponins through the cellular internalization and localization in lysosomes; leading to cell death [18]. Saponins have been highly studied in plants and macroalgae but there are fewer studies of saponins and their biological activities in $S$. platensis. In our study, saponins treatment of MCF7 and HepG2 cell lines led to spherical shapes but splitting was observed in MDA cells. The lysis of the cells in HepG2 and MCF7 cell lines was detected in the high concentration of saponins. It was suggested that saponins have the ability to induce apoptosis in treating cancer cell lines [19]. Our results showed morphological changes in all of the selected cell lines. These observed changes can induce apoptosis in HepG2, MDA, and MCF7 cell lines.

The presence of saponins in S. platensis was approved in some experiments $[3,5,20,21]$ but there is no report about the saponin content of this microalga and its activity. In our study, total obtained saponin content was $28 \pm 0.0005 \mathrm{mg} / \mathrm{g}$ dry wt of S. platensis which is equivalent to $2.8 \%$ dry wt. Total saponin content in the Spirogyra $s p$, one of filamentous freshwater green algae, was determined $2.5 \mathrm{mg} / \mathrm{g}$, which is much less than Spirulina [22]. Kanan et al., have reported one spot of isolated saponins from $S$. platensis with an $\mathrm{Rf}$ value of 0.65 ; using the solvent system with a mixture of chloroform: glacial acetic acid: methanol: water $(64: 34: 12: 8)$ [23]. In the current study, four spots of isolated saponins were observed in TLC testes with Rf values of $(0.44$, $0.48,0.50,0.55)$; using a solvent system with a mixture of ammonium: ethanol: n-butanol (7.5: 2.5: 10.5). Contrary to the previous study, the presence of different types of saponins was indicated in $S$. platensis. MCF-7 and HepG2 cell lines showed similar results in antiproliferation activity in similar concentrations of saponins. After $24 \mathrm{~h}$ treatment, IC 50 values of the cell lines was $0.350 \pm 0.055 \mathrm{mg} / \mathrm{ml}$ and $0.400 \pm 0.036 \mathrm{mg} / \mathrm{ml}$, respectively. However,IC50 value of MDA-MB-231 was $0.220 \pm 0.038 \mathrm{mg} / \mathrm{ml}$. Tukey tests showed that $1 \mathrm{mg} / \mathrm{ml}$ of saponins can inhibit $85 \%$ of cell growth in MCF7 and HepG2 cells. In the same concentration of saponins, $70 \%$ of cell growth inhibition was observed in MDA cells. Statistical analysis of MTT assay in MDA cells didn't show a significant difference between 0.4 and $1 \mathrm{mg} /$ $\mathrm{ml}$ of saponins and $70 \%$ of cell growth inhibition was observed at $0.4 \mathrm{mg} / \mathrm{ml}$. There are some reports about the cytotoxic effect of methanolic extract from $S$. platensis on cancer cell lines. Fayyad et al., have reported that methanolic extract has antiproliferative properties against MCF-7 and mice intestine carcinoma cell lines (L20B). The highest growth inhibition was observed in $25 \mathrm{mg} / \mathrm{mL}$ and $12.5 \mathrm{mg} /$ $\mathrm{ml}$ of methanolic extract against L20B (32.5\%) and MCF7 (71.5\%) [24]. However, there are no reports of antiproliferative effects of isolated saponins from $S$. platensis. Nevertheless, anticancer activities of isolated saponins from other algae, plants, and herbal medicines are reported. Saponins that were extracted from the marine red alga (Laurencia mariannensis) have shown cytotoxic activity against p-388 cell lines with an IC50 value of $0.6 \mathrm{mg} / \mathrm{ml}$ [11]. Bao et al., have extracted Sarsapogenin from Anemarrhena asphodelodes (Liliaceae) and evaluated the cytotoxic effect of this component on HepG2 cells. This extract has shown cytotoxic effects on HepG2 cells with an IC50 value of $42.4 \mu \mathrm{g} / \mathrm{ml}$ and $25 \mu \mathrm{g} / \mathrm{ml}$ after treatment for $48 \mathrm{~h}$ and $72 \mathrm{~h}$, respectively. Saponins from Cimicifuga $s p$. were tested in MDA-MB-453 and MCF-7 as two human breast cancer lines. The MCf-7 cell lines were found much more resistant to saponin treatment [10]. In our study, MCF-7 and HepG2 cells were more resistant to treatment with saponins isolated from Spirulina, compared to MDA. In a study by alam et al, the cytotoxic effect of saponins extracted from Zanthoxylum armatum (Z. armatum) was evaluated at $100 \mu \mathrm{g} / \mathrm{ml}$ in MTT assays on MCF-7 and MDA-MB-468. Saponins of $Z$. armatum fruit showed growth inhibition by $79.89 \%$ in MCF-7 and by $95 \%$ in MDA-MB-468. Saponins of $Z$. armatum caused growth inhibition in $9.43 \%$ and $94.59 \%$ of MCF-7 and MDA-MB-468, respectively. Saponins of $Z$. armatum leaves showed growth inhibition by $49.08 \%$ in MCF-7 and $85.33 \%$ in MDA-MB-468 [19]. In our study, saponins isolated from $S$. platensis at a concentration of 100 $\mu \mathrm{g} / \mathrm{ml}$ has showed $20 \%$ and $31 \%$ growth inhibition in mcf-7 and MDA-MB-123, respectively. Isolated saponins from Spirulina have not shown a cytotoxic 
effect on human dermal fibroblast (HDF) cell line because of its high IC50 value.

Despite the importance of saponins, there are few studies about these compounds in Spirulina. Many studies demonstrated that saponins isolated from algae and plants can inhibit the proliferation of cancer cell lines. Our results showed the antiproliferation activity of Spirulina isolated saponin.

\section{ACKNOWLEDGEMENTS}

We gratefully acknowledge Dr. Hejazi (Agricultural Biotechnology Research Institute of Iran) for supplying the strain of Spirulina that was used in this study.

\section{CONFLICT OF INTEREST}

The authors declared no conflict of interest.

\section{ETHICS APPROVAL}

This study was approved by the Ethics Committee of Iranian Research Organization for Science and Technology.

\section{REFERENCES}

1. Caicedo NH, Kumirska J, Neumann J, Stolte S, Thoming J. Detection of bioactive Exometabolites Produced by the filamentous Marine Cyanobacterium Geitlerinema sp. Mar Biotechnol (NY). 2012;14(4):436-45. DOI: 10.1007/ s10126-011-9424-1 PMID: 22160344.

2. Tohme R, Darwiche N, Gali-Muhtasib H. A Journey Under the Sea: The Quest for Marine Anti-Cancer Alkaloids. Molecules. 2011;16(11):9665-96. DOI: 10.3390/molecules16119665 PMID: 22113577.

3. Agustini TW, Suzery M, Sutrisnanto D, Ma'ruf WF, Hadiyanto. Comparative Study of Bioactive Substances Extracted from Fresh and Dried Spirulina sp. Procedia Environ Sci. 2015;23:282-9. DOI: 10.1016/j.proenv.2015.01.042.

4. Gacheva GV, Gigova LG. Biological Activity of Microalgae Can be Enhanced by Manipulating the Cultivation Temperature and Irradiance. Cent Eur J Biol. 2014;9(12):116881. DOI: $10.2478 / \mathrm{s} 11535-014-0350-\mathrm{x}$.

5. Sudha SS, Karthic R, Rengaramanujam J, Athulya. Antimicrobial Activity of Spirulina platensis and Aphanothece sp. on Selected Clinical Bacterial Isolates and Its Antioxidant Activity. South As J Biol Sci. 2011;1(2):87-98.

6. Henrikson R. Spirulina World Food: How this Micro Algae Can Transform Your Health and Our Planet. 6th ed. Hana, Maui, Hawaii, USA: Ronore Enterprises, Incorporated; 2010.

7. Mohd Syahril MZ, Roshani O, Nur Hasyimah R, Mohamad Hafiz MS, Sharida MD, Ahmed HY. Screening of Anticancer Activities of Crude Extracts of Unicellular Green Algae (Chlorella vulgaris) and Filamentous Blue Green Algae
(Spirulina platensis) on Selected Cancer Cell Lines. International Conference on Applied Sciences, Mathematics and Humanities. 2011.

8. Yildırım I, Kutlu T. Anticancer Agents: Saponin and Tannin. Int J Biol Chem. 2015;9(6):332-40. DOI: 10.3923/ ijbc.2015.332.340.

9. Xu XH, Li T, Fong CM, Chen X, Chen XJ, Wang YT, et al. Saponins from Chinese Medicines as Anticancer Agents. Molecules. 2016;21(10). DOI: 10.3390/molecules21101326 PMID: 27782048 .

10. Podolak I, Galanty A, Sobolewska D. Saponins as Cytotoxic Agents: A Review. Phytochem Rev. 2010;9(3):425-74. DOI: $10.1007 / \mathrm{s} 11101-010-9183-\mathrm{z}$ PMID: 20835386.

11. Li YX, Himaya SW, Kim SK. Triterpenoids of Marine Origin As Anti-Cancer Agents. Molecules. 2013;18(7):7886909. DOI: 10.3390/molecules 18077886 PMID: 23884125.

12. Sarada R, Pillai MG, Ravishankar GA. Phycocyanin from Spirulina sp: Influence of Processing of Biomass on Phycocyanin Yield, Analysis of Efficacy of Extraction Methods and Stability Studies on Phycocyanin. Process Biochem. 1999;34(8):795-801.

13. Shanab SMM, Mostafa SSM, Shalaby EA, Mahmoud GI. Aqueous Extracts of Microalgae Exhibit Antioxidant and Anticancer Activities. Asian Pac J Trop Biomed. 2012;2(8):608-15. DOI: 10.1016/S2221-1691(12)60106-3.

14. Majinda RR. Extraction and Isolation of Saponins. Methods Mol Biol. 2012;864:415-26. DOI: 10.1007/978-161779-624-1_16 PMID: 22367906.

15. Wagner H, Bladt S. Plant Drug Analysis: A Thin Layer Chromatography Atlas. 2nd ed. Berlin, Heidelberg, Germany: Springer-Verlag; 1996. DOI: 10.1007/978-3-64200574-9.

16. Ebrahimi Nigjeh S, Yusoff FM, Mohamed Alitheen NB, Rasoli M, Keong YS, Omar AR. Cytotoxic Effect of Ethanol Extract of Microalga, Chaetoceros Calcitrans, and Its Mechanisms in Inducing Apoptosis in Human Breast Cancer Cell Line. Biomed Res Int. 2013;2013:783690. DOI: 10.1155/2013/783690 PMID: 23509778.

17. Zaid AAA, Hammad DM, Sharaf EM. Antioxidant and Anticancer Activity of Spirulina platensis Water Extracts. Int J Pharmacol. 2015;11(7):846-51. DOI: 10.3923/ ijp.2015.846.851.

18. Wang Y, Zhang Y, Yu B. The Cytotoxicity of Saponins Correlates with their Cellular Internalization. Chem Med Chem. 2007;2(3):288-91. DOI: 10.1002/cmdc.200600235 PMID: 17200998 .

19. Alam F, Najum Us Saqib Q, Waheed A. Cytotoxic Activity of Extracts and Crude Saponins from Zanthoxylum Armatum DC against Human Breast (MCF-7, MDA-MB-468) and Colorectal (Caco-2) Cancer Cell Lines. BMC Complement Altern Med. 2017;17(1):368. DOI: 10.1186/s12906017-1882-1 PMID: 28716103.

20. Anchang KY, Lewis D, Nji C. Toxicological, Phytochemical, and Antibacterial Assessment of Chlorella vulgaris and Spirulina platensis Powder in Albino Rats. A Preliminary Study. Rev Peru Med Integr. 2016;1(3):5-11. DOI: 10.26722/rpmi.2016.13.21.

21. Albert N, Wague R, Mbaïlao M, Fabienne N. Changes 
in the Physico-Chemical Properties of Spirulina platensis from Three Production Sites in Chad. J Anim Plant Sci. 2012;13(3):1811-22.

22. Champa P, Whangchai N, Jaturonglumlert S, Nakao N, Whangchai K. Determination of Phytochemical Compound from Spirogyra sp. Using Ultrasonic Assisted Extraction. Int J GEOMATE. 2016;11(2):2391-6. DOI: 10.21660/2016.24.1277.
23. Kannan M, Pushparaj A, Dheeba B, Nageshwari K, Kannan K. Phytochemical Screening and Antioxidant Activity of Marine Algae gracilaria Corticata and Spirulina platensis. J Chem Pharm Res. 2014;6(11):312-8.

24. Fayyad RJ, Mohammed Ali AN, Dwaish AS, Khayoon A. Anticancer Activity of Spirulina platensis Methanolic Extracts against 120b and MCF7 Human Cancer Cell Lines. Plant Arch. 2019;19(1):1419-26. 